\title{
Innovative Science Trends That Have Occurred in Zimbabwe
}

\author{
Anna Gudyanga ${ }^{1}$, Ephias Gudyanga ${ }^{1} \&$ Judith $_{\text {Mutemeri }}{ }^{1}$ \\ ${ }^{1}$ Faculty of Education, Midlands State University, Gweru, Zimbabwe \\ Correspondence: Anna Gudyanga, Faculty of Education, Midlands State University, Gweru, Zimbabwe. Tel: \\ 263-7-7342-0631. E-mail: gudyangaa@msu.ac.zw
}

\author{
Received: February 12, 2013 Accepted: June 7, 2013 Online Published: August 30, 2013 \\ doi:10.5539/ass.v9n11p50 \\ URL: http://dx.doi.org/10.5539/ass.v9n11p50
}

\begin{abstract}
This paper seeks to expose what innovative teaching there is in the Zimbabwean science-teaching context, as well as what opportunities and what challenges there are. Science is the mother of all technology hence no sustainable development can take place in any country without talking about science. Qualitative methodology was used where questionnaires, focus groups and observations were the main tools for this study. Triangulated data was analysed and results showed that from the time Zimbabwe attained independence in 1980, the government has put in place five innovative projects to improve the delivery of science teaching in schools, some of which are Zimbabwe Science Project, Quality Education in Science Teaching and the Science Education In-service Teacher Programme. Teachers are engaging students in hands on activities (Interactive Teaching Strategy), group work, seeding discussion while problem solving, demonstrations, questioning thus providing students with a multi - sensory learning experience. The challenges include brain drain of science teachers into industry and inadequate resources. We recommend that schools must offer the foundation for developing computer skills and knowledge and fund raise to alleviate the shortage of resources.
\end{abstract}

Keywords: innovative, teaching, challenges

\section{Introduction}

Zimbabwe has witnessed dramatic change in the environment emanating from explosive technological growth and innovations in global communication. Schools are faced with serious socio- economic and socio- political challenges which are becoming more and more complex with time (Nziramasanga, 1999). Science and technology education are seen as a vehicle for economic and social development of any country (Chisman, 1984). Science and technology have long been recognised (Asiemeng-Boahene, 2006) as the corner stone of development and prosperity in Africa. In other words economic prosperity is inter-linked with its utilisation and management of science and technology.

It is important to note that knowledge is being multiplied exponentially in today's world. Since the rate at which knowledge in science today gets obsolete is very high, it is essential that the emphasis of science education should be the development of abilities and dispositions of mind rather than merely the transfer of dead subject matter. There is therefore need to develop a scientific temper in the educant, through innovative science teaching.

Being in the education system for the past thirty- years, we have observed that today's schools emphasise a teacher who lectures, marks assignments and dictates what to study and read. Children are expected to be passive learners or passive receivers of knowledge rather than taking an active role in their own education. Rote memorisation and surface inquiry seem to take the place of deeper learning as the teacher determines what children must know and when they may know it. Traditionally, teachers have assumed that the students learn through lectures, assigned readings, problem sets and laboratory work. Yet we have all been frustrated by the frequent failure of our students to learn basic scientific concepts. Students are often not able to discuss and to reflect on difficult material because of the pace and large enrolments of many science subjects. Evidence is mounting that these traditional methods are less effective than we once thought, (Pearsall, 1992) in helping our students to develop an understanding of the science concepts that are being taught. Therefore this paper seeks to find out the innovative trends that have occurred in Zimbabwe.

\section{Theoretical Framework}

Huberman (1974) in Horton and Raggatt (1982), defines innovation as ..."the creative selection, organisation and utilisation of human and material resources in new and unique ways, which will result in the attainment of a 
higher level of achievement of the defined goals and objectives" (p.119). It can be deduced that an innovative teacher's role is to integrate the science of learning with the art of teaching. A teacher should involve pupils in the learning process by using a hands-on approach, which is effective for teaching all students regardless of cultural background.

Havelock (1973) defines innovation as a change, which benefits the people who are changed. This means therefore that teachers should not say I do not have a test tube or beaker, so I cannot teach science. Our focus should be on the development of low cost improvised teaching aids on zero cost budgets. Science cannot be taught by traditional chalk and talk method alone. It cannot always and all the time be taught within the four walls of the classroom. Nothing of educational value is lost if the students are taken away for varying length of time from the classroom with the view of teaching science for example, to explain the working of an electric motor, we can take the services of the electric motor mechanic. To teach the electrolysis of water or the haber process i.e. the manufacture of ammonia and manufacture of ammonium nitrate (fertiliser), students could be taken to a fertiliser manufacturing company like Sable Chemicals in Kwekwe, Zimbabwe, where they actually observe the processing operation and explanations made. Horton and Raggatt (1982) said that innovations are planned and implemented by people. Innovative teaching is to be learner centred. We believe that children learn best through an active discovery process that capitalizes on their innate curiosity, concentration and passion for learning. If we develop a scientific mind in our children, we are developing our nation economically. With a developed economy, a country can achieve sustainable development in all spheres.

Science can be described as a way of knowing, or a method that involves disciplined inquiry in the creation of new knowledge. Teaching is a process to learning. One of the most critical issues in science education is what determines quality teaching and learning. Quality teaching is recognised as one of the most important elements in the improvement of education, (UNESCO, 1993). Teachers are encouraged to use different and innovative teaching methods. Diversity enriches an otherwise monotonous situation; the differences may offer other perspectives, widen one's horizon or improve one's understanding of things. Scientific knowledge has to benefit humanity. Meena (1992) says that in Africa, poverty is partly attributed to lack of scientific knowledge and its application in the production process; hence for any sustainable development, scientific knowledge and its application play a pivotal role.

The teacher as the chief curriculum implementer is a critical factor in science teaching hence teacher innovativeness is paramount. Quality teaching and learning involves effective use of time and command of the subject matter. What happens in the classroom and in the school, explain the variance in the learner achievement inclusive of other related factors such as availability of textbooks, apparatus, chemicals, equipment and science laboratories (Dunbar, 1995). Effective successful teaching can be measured by what the teacher does, by what pupils become after teaching and by the interaction between the teacher and pupils. Teachers are encouraged to move away from the straight lecture-test, to an environment that is more student-centred. It is important to note that science requires active learning techniques such as group problem solving, problem-based learning, the use of case studies and inquiry based on laboratories. These active and innovative teaching methods or techniques provide a much more effective environment in which students can learn. Hence science teachers should have some novelty skills in planning and organising lessons.

Johnson et al., (1991) advocate for new teaching paradigm (as compared to the traditional paradigm explained before), which is to help students construct their knowledge in an active way while working cooperatively with classmates so that students' talents and competencies are developed. The principal activities under this new paradigm are:

1) Knowledge is constructed, discovered and extended by students. Students construct meaning from the material presented by the teacher.

2) Students actively construct their own knowledge, that is, learning is done by the learner and not done by the teacher.

3) Teacher effort is aimed at developing students' competencies and talents, which are considered to be dynamic and susceptible to change.

4) Education is a personal transaction among students and between teacher and students as they work together. As a social process, much learning occurs through interpersonal interaction and thus positive relationships in the learning environment are important. 
5) All of the above can take place within a cooperative context. Competitive learning situations minimize communication and discourage active construction of knowledge and talent development because of negative relationships and

6) Teaching is assumed to be a complex application of theory and research that requires considerable instructor training and continuous refinement of skills and procedures (Johnston et al., 1991).

\section{Methodology}

Qualitative research design was followed. Three instruments were used to collect triangulated data, namely questionnaires, focus groups and observations. Convenience sampling was used to select three high schools (one of which was a rural school). A total of fifteen science teachers (five from each of the three schools) and one science Education Officer completed a questionnaire concerning the innovative teaching there is in the Zimbabwean science teaching context, as well as what opportunities and what challenges there are. All science teachers in a school formed a focus group and hence a total of three focus group interviews were conducted. The focus group in essence is a conversation with a purpose. This method provided a means to check the authenticity of data and improve the credibility of results. The aim of the focus group interviews was to find out to what extent the Zimbabwean science teachers are innovative and the effects this could have in the teaching and learning of science. A voice recorder was used in order to maintain an uninterrupted flow of interaction during interviews.

Random sampling was used to select one teacher from each of the three schools, whose lessons were observed to find out to what extent science teachers are innovative. All the science teachers including the Education Officer had a degree qualification each. Data was analysed using simple themes derived from responses by participants. The recorded interviews allowed the researchers to obtain a deeper level of meaning and to make important connections or relationships in the data.

\section{Results}

There was a $100 \%$ questionnaire return. All the fifteen teachers and the Science Education Officer for the Region understood and explained the meaning of innovation. They argued that it is the introduction of new things in a creative, organised and unique way to get students excited about science learning or the new ways of utilizing human and material resources by the breaking away from the norm and doing something that is fun while learning, its more than improvising apparatus and chemicals while teaching. They also said that these creative ways of teaching should include the use of technology as a tool that promotes learning. Technology plays an important role in communication and in finding out information. Innovation therefore calls for a new way of thinking in order to bring about development of any nation.

The second question, asked for efforts being taken or have been taken to improve the delivery of science education in Zimbabwean schools. The results showed that there are five innovations geared to improve the delivery of science in schools. These are as follows:

\subsection{Zimbabwe Science}

In an endeavour to improve the teaching of science by providing a sound science education in the rural schools, where there is no electricity, the government launched the Zimbabwe science project. The project sent to schools science kits which were complete with basic science equipment with the possibility to replenish them. The project provided children in rural secondary schools with a meaningful science curriculum and ensured sustainable participation in the science education for the majority of the country's secondary schools. The Nziramasanga report (1999) said that Zim-science approach can perform just like the traditional system and many traditional schools are switching onto Zim-science because they find it more sustainable. Evaluation reports maintained that this approach required a good administration and distribution structure. The project received wide acclaim internationally to the extent that the World Bank used it in its educational redevelopment projects in other countries. For instance, Botswana implemented a similar model using kits purchased from Zimbabwe (Nziramasanga, 1999). In 1989, Zim-science project won the UNESCO Jon Amos Commenius award for excellence in innovation in the teaching of science.

\subsection{Quality Education in Science Teaching (QUEST) Project}

The project is currently running. This was designed to decentralise in-service training courses and empower teachers to make decisions about issues that affect them at school level. It caters for form one up to form four teachers. Quest in-services teachers through the cascade model of skills transfer where trained resource persons manning districts resource centres train heads of science departments. These teachers in turn train teachers in their departments. Quest, thus provides teachers with a forum for sharing ideas and discussing problems. 
Nziramasamga report says that seventy-seven science district resource centres were established. These resource centres are managed by two trained science advisers who among other things, fund raise and determine the needs in their districts with the intension of looking for ways through dialogue and workshops of addressing them.

\subsection{The Science Education In-Service Teacher-Training Program (SEITT)}

SEITT is yet another staff development organ which caters for Advanced Level (A' level) science and mathematics teachers. SEITT has established resource centres managed by science advisers. The advisers have a Diploma in Science Education awarded by the University of Zimbabwe. SEITT also offers a forum for A' level teachers to interact, share ideas and in most cases solve problems faced by isolated science teachers.

\subsection{The Better Environment Science Teaching (BEST)}

This is bedrock of science teaching at primary level. This program led to the writing of a new primary science syllabus and in servicing of teachers, heads, District Education Officers and Education Officers. Its advantage is that it uses the environment as the laboratory for biological and physical sciences. The conceptual framework and implementation of the project is led by Zimbabwe while the funding is provided by the German agency for technical cooperation. Its weakness is that adequate steps have not been taken to secure local funding in the event of the donor moving out.

\subsection{Business Education Partnership of Zimbabwe (BEPAZ) Program}

BEPAZ is a partnership forged between Ministry of Education and the business community to promote technical vocational education in the school system. Business contributes money, which is used to enhance teaching and training in areas with a Technical-Vocational bias. This, they do through such programmes like the school on the shop-flow and teacher placement which are intended to expose both secondary school students and their teachers to the world of working in general, and to a new technology in particular.

There is a concerted effort to introduce computers to all schools in Zimbabwe. A World Bank project is in progress to install computers throughout the country. At secondary school level, a few schools offer computer studies but most schools teach technical subjects such as wood technology, metal craft, technical graphics and building. Colleges and Universities offer electronics, computers, engineering, science technology, textile technology, wood technology and others, (Nziramasanga, 1999). A lot of opportunities for innovation are found in Zimbabwe.

The following was said by teachers to answer the question whether science teachers are innovative in the teaching of science and the effect this could have in the learning and teaching of science. Students lose interest in science hence we are engaging students in hands-on activities, while using students' own experiences to teach science. It is important to note that children learn best through an active discovery process that capitalizes on their curiosity. From the Chinese saying what I hear, I forget what I see I remember but what I do, I understand. Teachers are providing students with a multi- sensory learning experience to improve their academic performances. The teachers were also encouraging group work where students learn through shared experiences. They also said that students enjoy getting out of the classroom using their imaginations while learning.

The major constraint if discovery learning is not teacher controlled is the time to cover the syllabus. The teachers helped the students by employing a range of active learning approaches (like talking and listening, writing, reading and reflecting) and varied teaching techniques or strategies (such as teacher exposition, demonstrations, experimentation in the laboratory and collaborative groups). Use of a variety of teaching method can help students make sense of the world in different ways while increasing the likelihood of developing conceptual understanding. The teachers also said that they are improvising some apparatus for example, the jam tin for beakers, large tins for water troughs etc. Instead of using expensive enzymes, teachers are using saliva. A student will be using his or her own saliva during experiments. The teachers share ideas through projects such as SEITT or QUEST.

Focus group interviews revealed further information. The results reinforced other findings, that innovative teaching in science must concentrate on hands-on approach to the subject, be it maths, physics, biology, chemistry or integrated science. They also said that teachers have to try and make demonstrations entertaining as well as instructive while at the same time warning students not to get caught up in the excitement and miss the point of experiments. They said that the students should keep their minds on what happened and why it happened, writing down the physical principle that was illustrated.

Some teachers said studying in small groups works well for students. It can teach someone else a difficult concept, it really increases their own understanding; Bring life to the subject one teaches; Demonstrate things that would get students excited about a particular aspect of learning. From the discussion, teachers agreed that 
the teacher's intention is to be unpredictable by keeping what one intends to do as a secret until the last minute. This is because being unpredictable enhances the surprise effect because surprise adds to motivation. Teachers therefore should never be out of ideas of how to hook students on the long-term value of learning. When teaching, teachers should not just tell students but letting them experiment and discover on their own the scientific concepts. They agreed that there isn't one specific way of teaching and that it varies with each student and his ability to grasp what is being imparted. Hence science teachers need to have an innovative mind for them to get to the heart of quality science teaching, on which development of any nation hinges.

\subsection{Class Observations}

Though the teachers knew what innovative teaching is from the focus group interviews. Some of the issues they put across did not occur in the classroom e.g. some of the experiments were not carried out due to shortage of resources, there was no emphasis of student initiated work but what the students learnt was teacher initiated. Most lessons were student-friendly and activity centred i.e. discussions in groups, report back presentations and write-ups. Students were driven to think, apply prior knowledge, and interact with their peers. Other lessons were teacher centred especially when teacher was teaching weak students. They seemed more interested in covering the syllabus at the expense of student understanding. The level of willingness to the use of teaching aids was found low and this was due to the insufficient funds (socio- economic constraints).

Some teachers went outside the textbook to relate science application to real world problems. Teachers were teaching by questioning and this is better than the more traditional approach of teaching by telling. Some teachers were very dedicated to their work, loving and passionate while others were very authoritative, harsh thus creating a tense atmosphere. The latter would say do you have any questions? Rather than asking students for their questions e.g. what questions do you have? This implies that the teacher expects questions and is encouraging students to ask them unlike the former, which looks rather threatening.

We also observed that even in laboratories, $A^{\prime}$ level students were experimenting either in groups of 3 to 4 , pairs or individually (depending on the type of experiment) to collect data and then work independently to write their reports. Experiments in groups were due to shortage of apparatus and chemicals. The teachers were helping students become active learners by motivating them with open ended questions such as, what happens when---? Why does that happen? But how can that be when we know that---? Students need to talk with peers and teachers in order to articulate what they have experienced during experimentation. Thus one A' level teacher said, I don 't give my students answers, but I give them questions. If they live school knowing what questions to ask and how to go about finding answers, they will be able to apply their learning in the world outside school. If, instead they leave with answers, they will be perhaps a misfit in the real world which has lots of unanswered questions. This is because scientific knowledge is never at a standstill; it is dynamic and an ongoing process.

Another teacher after observation said I have decided to stop teaching by telling, and switched on to teaching by questions. Science learning therefore must be an interactive process in which students become engaged with scientific phenomena and debate with both peers and teachers in-order to develop a full understanding of related phenomena and underlying concepts. When science is only taught as a set of truths, we run the risk of subverting our students' attempts to grapple with problems and make new experiences meaningful. We deny them the opportunity to engage in the scientific process.

\section{Discussion}

There has been a brain drain of science teachers to industry because of poor remuneration in the teaching service. Quality science education requires qualified teachers, laboratories, textbooks, facilities and equipment to enable Zimbabwe to provide science education to a large population with very limited resources. In other words, there are resource problems: equipment, large classes, infrastructure barriers and inappropriate textbooks and insufficient textbooks. A lot of innovation is called for in order to satisfy the people's aspirations. Most teachers do not know how to use a computer, let alone how to use Information Technology Communication (ITC).

The projects like BEST, QUEST, SEITT and BEPAZ try to improve the teaching, delivery and learning of science, which address a common discipline but are supported and funded by different donor agencies. Nziramasanga Commission (1999) noted a lack of co-ordination between these projects resulting in a duplication of effort after creating conflict on the field. Schools not adequately equipped with computers and lack of funds to maintain their existing computers in good working condition are other challenges we found. Poole (1996) says computer illiteracy is now called new illiteracy which has forced most schools to be equipped with computers and qualified staff to produce technologically proficient and efficient students. Students need to be highly skilled and competitive in the labour global market in order to bring about sustainable development. 
Despite these challenges, science teachers are working towards being innovative. They have the ability to arouse and sustain motivation and interest and application of varied methods. The challenge to the teacher is to use this diversity to help mould the best-educated member of society that is possible. Teaching is therefore a function that needs training and continued improvement of strategies to be more effective. Students need to be very much involved in discovering the information and retaining this information as it is associated with some structure in their frame of reference and in analysing, modifying and applying the same under new situations. This enhances the students' analytical and problem solving skills in the process. An innovative teacher should engage the student in the whole learning process i.e. constructing, discovering, transforming and extending the new information and the teacher helping to direct the learning process. An innovative teacher should be able to plan and organise individual and group activities. S/he must also have the ability to economically use teaching and learning aids, and all other resources like time appropriately. An innovative teacher should also be able to handle learners of different intellectual and learning (dis)abilities and have should have acquired skills of good classroom management. S/he must also be able to make use of good questioning techniques. Science teachers should create a learning environment that enables students to transit from a science classroom to a research laboratory. In other words science classes must be translated into real world applications. A key feature of effective teaching is the selection of instructional materials that meet the needs of students, the teaching and learning environment. Instructional materials need to be student centred and not teacher centred. Teachers are to be fair, firm, and consistent and teach in an effective and innovative way that students will remember them.

\section{Conclusion}

There is need to promote learning and teaching through the use of internet thus producing students who are competitive in the global labour market. Schools must offer the foundation for developing computer skills and knowledge and hence developing the future workforce of a country. There is need to irrigate the probing of scientific minds.

Students ought to:

1) Be inquisitive about things and events

2) Have the courage to question belief and practices

3) Ask what, how and why and find out answers by critically observing, experimenting, consulting, discussing and reasoning.

4) Record honestly observation and experimental results in a laboratory and outside it. Repeat experiments carefully and systematically if required but do not manipulate or cook results under any circumstance

5) Be guided by facts, reason and logic. Do not be biased in one way or the other

6) Aspire to make new discoveries in inventions by sustained and dedicated work.

In conclusion this study can help teachers to reflect their own teaching practices and the analysis of data could lead to improvement in science teaching in our educating system, thus bringing about development of a country. We can therefore happily say that we cannot teach a man anything but we can only help him discover it for himself. This is because people use their experiences to build mental frameworks that help them make sense of the world. They use these mental frameworks to interpret the information, to make generalisations or predictions when they encounter a strange phenomenon. The familiar, Ah ha! Now I get it reflects students' active wrestling with a new idea and successful modification or adaptation of mental frameworks.

\section{References}

Asimeng-Boahene, L. (2006).Gender inequality in science and mathematics education in Africa: The causes, consequences and solutions. Education Journal, 126(4), 711-728. Retrieved from http:www.projectinnvation.biz/educational.html on the03/06/2012

Chrisman, D. J. (1984). Science Education and National Development. Science Education, 63(5), 63-569.

Dunbar, K. (1995). How scientists really reason: Scientific reasoning in real world laboratories. Mechanisms of Insight, Mass MIT Press, Cambridge.

Havelock, R. G. (1973). The Change Agents Guide to Innovation in Education. New Jersey: Educational Technology Publishing.

Horton, T., \& Raggatt, T. (1982). Challenge and change in the curriculum. Hodder and Stoughton, Bungay.

Huberman, A. M. (1974). Understanding change in education. UNESCO International Bureau of education, Geneva. 
Johnson, P. W., Johnson, R. T., \& Smith, K. A. (1991). Active Learning: Cooperation in the college classroom. Edna, M N: Interaction Book Company.

Kydd, L. (1997). Professional Development for Educational Management. Leadership and Management in Education. Open University, Megan Crawford.

Meena, R. (1992). Gender in Southern Africa Conceptual and Theoretical Issues. Jongwe Printers, Harare.

Nziramasanga, C. (1999). The Nziramasanga report of the Presidential commission of inquiry into education and training in Zimbabwe. Harare: Government Press.

Pearsall, D. M. (Eds.) (1992). Ethnoecology, Biodiversity and Modernisation in Andean Potato Agriculture. Journal of Ethnobiology, 12(2) 34-46.

Poole, G. A. (1996). A New Gulf in American Education. The Digital device. New York Times. New York.

Raj, H. (2000). Theory and practice in Social Science Research. Edition Subject Publication, New Delhi.

UNESCO. (1993). School based In - Service Training A handbook. Bangkok, UNESCO.

\section{Copyrights}

Copyright for this article is retained by the author(s), with first publication rights granted to the journal.

This is an open-access article distributed under the terms and conditions of the Creative Commons Attribution license (http://creativecommons.org/licenses/by/3.0/). 